\title{
Policy Implementation of Employment Opportunity for Persons with Disabilities in Pekanbaru City Government Agencies
}

\author{
${ }^{1}$ Daffa Nadya Adriana, Sujianto
}

${ }^{1}$ Universitas Riau, Indonesia; dnadyaadriana@gmail.com

Received: July 22, 2021; In Revised: November 28, 2021; Accepted: December 17, 2021

\begin{abstract}
The employment opportunity policy for persons with disabilities is established by the Government that aims to provide employment opportunities and create employment opportunities for persons with disabilities to create equal employment rights between persons with disabilities and normal society so that discrimination against persons with disabilities can be prevented is eliminated. This study aims to look at the implementation of employment opportunities policies for persons with disabilities in Pekanbaru City and the factors that influence the performance of these policies. The research method is descriptive qualitative data collection techniques using interviews, observation, and documentation. The results of this study are the finding of deficiencies that must be considered to be improved, namely in implementing responsiveness (lack of socialization) so that policy implementation has not run optimally in Pekanbaru City. Researchers also found several factors that influence the implementation of this policy in Pekanbaru City, namely the objectives of the policy, human resources, economic conditions, as well as the response and participation of the target group.
\end{abstract}

Keywords: Implementation, job opportunities, persons with disabilities

\section{Introduction}

Citizens' equal rights refer to equality in all elements of life for every citizen in a country. Political, economic, socio-cultural, educational, and, of course, legal rights are all included. Ethnicities, cultures, religions, groups, customs, and physical conditions vary significantly among Indonesians. Every citizen's equal rights must be non-discriminatory, with no distinction made between individuals based on their circumstances, and all citizens have the same rights. Jenkins defined public policy as a sequence of interrelated decisions made by a person or group of political actors related to the goals that have been stated as well as strategies to attain those goals in given conditions (Wahab, 2016). In principle, decisions do not exceed the actor's power constraints. Public policy also must be linked to activity achieving a specific goal or objective. However, the plans of government operations are not always easy to fulfil, the idea that policies contain actions with a purpose (Agustino, 2016).

According to The 1945 Constitution, Articles 27 to 34 of Chapter X to Chapter XIV, every citizen has equal status in law and government, equality in labour and a decent existence (economy), equality of freedom of association and gathering (politics), and equality in human rights. Equality of rights necessitates that all citizens, especially vulnerable groups such as 
people with disabilities, be treated similarly by everyone. But, unfortunately, individuals with disabilities are rejected in all parts of life due to prejudice, stigma, discrimination, and the belief that people with impairments cannot enjoy a good life.

Persons with disabilities are members of the community who have the right to remain in the local community. In education, health, employment, and social services, people with disabilities must receive the required assistance. In terms of human rights, the rights of people with disabilities are classed as special rights for specific groups of people (Manan, 2001). According to Goffman (Ladipa et al., 2020), the leading social problem faced by people with disabilities is that they are not standard on a fundamental level, causing people around them to feel uncomfortable or unable to interact with them, with the perception that they are unable to do so on all counts and are the problem.

People with disabilities are grouped into three categories: people with physical disabilities, people with mental disabilities, people with physical and mental disabilities or multiple disabilities. People with physical disabilities consist of the physically disabled, the blind, the deaf, the speech impaired, and the chronically disabled. Mentally disabled and hardwired persons both suffer from mental disabilities. A person with physical and mental disabilities or multiple disabilities has two or more disabilities.

Persons with disabilities condition impairs their ability to participate in social life, leaving them in desperate need of encouragement and aid from those around them. People with disabilities face unquestionably more significant challenges than those faced by the general public, such as barriers to public services, education, health, and work. However, mental or physical disabilities should not prevent people from attaining constitutional rights. Lack of education, lack of skills training and professional training, lack of work prospects, lack of recognition, and lack of trust are all factors that contribute to the disparity in the lives of individuals with disabilities and those without disabilities.

Social welfare for those with impairments must be on par with citizens in ideal physical and mental health. On the other hand, many Indonesians continue to live in poverty, displaying signs of vulnerability, powerlessness, support, and inability to express their goals. According to figures from the Central Statistics Agency, the number of impoverished people in Indonesia in 2019 was estimated to be 25.14 million, or $9.82 \%$ of the overall population (BPS, March 2019). This number fell by 530 thousand persons from September 2018 to March 2018 and 805 thousand persons from March 2018 to September 2018.

The Riau Province Regional Regulation Number 18 of 2013 concerning the Protection and Empowerment of Persons with Disabilities states that every person with a disability has the same opportunity and treatment in obtaining a job according to their abilities, competencies, types, and types degrees of disability. One of the most severe issues that people with impairments confront is finding work. According to Sumarsono (Habibi \& Nugroho, 2019), job opportunities in occupations that have been filled and still vacant or have not been filled. Meanwhile, according to W. Sravistha (Priyono \& Wirathi, 2016), job opportunities is conditions that indicate the number of available jobs that the workforce can accept.

According to Van Meter and Van Horn (Winarno, 2008), policy implementation is an activity based on a previous decision. The action encompasses decision making efforts and activities at a certain point in time, as well as big and small policy efforts indicated by the policy, the implementation of which leads to the set objectives. Daniel A. Mazmanian and Paul Sabatier define implementation as knowing what happens before a program is declared valid or formed. Therefore, the events and actions that occur prior to adopting guidelines in the country that 
contain efforts to administer and generate real consequences or effects on events or society are the focus of attention (Wahab, 2008).

Many disabled people in Pekanbaru require employment. Nowadays, the considerable number of disabled individuals is undoubtedly a significant source of concern for the Pekanbaru City Government, especially Badan Kepegawaian dan Pengembangan Sumber Daya Manusia (BKPSDM) Pekanbaru. According to data from BKPSDM Pekanbaru, 933 persons with disabilities in Pekanbaru City in November 2019. However, the figure is still fluctuating because many people with disabilities do not want to be documented (BKPSDM, November 2019).

In order to address the problem of people with disabilities, the government opens up employment opportunities in government agencies through the acceptance of Civil Servant Candidates (CPNS), which takes place every year. At this CPNS acceptance, there are general formations that the general public can apply for if they meet the requirements and remarkable formations for people who meet specific criteria. Conditions or measures that are in accordance with the implementation of the CPNS selection within the Pekanbaru City Government in 2019, namely from persons with disabilities who are included in the physically disabled group and are required to have a certificate from the government explaining the type/level of disability with the ability to listen, speak well, perform tasks such as analyzing, typing, conveying thoughts, seeing thoughts and being able to move using assistive devices.

Since 2018, the government has opened a special formation for persons with disabilities for CPNS admissions. However, in 2019 there were only those who registered for this special formation for disabilities. It is possible that many people were unaware of this special formation for persons with disabilities in 2018. The following table presents the formation table for civil servants with disabilities in each district/city in Riau Province:

Table 1

Formation of CPNS with Disabilities in Each District/City in Riau Province in 2019

\begin{tabular}{ccc}
\hline District/City & $\begin{array}{c}\text { General Formation } \\
\text { (Can be applied by Persons with } \\
\text { Disabilities) }\end{array}$ & $\begin{array}{c}\text { Special Formation } \\
\text { for Persons with } \\
\text { Disabilities }\end{array}$ \\
\hline Bengkalis & - & 2 \\
Indragiri Hilir & 19 & 2 \\
Indragiri Hulu & - & 4 \\
Kampar & 1 & 1 \\
Kepulauan Meranti & - & 2 \\
Kuantan Singingi & - & 2 \\
Pelalawan & - & 2 \\
Rokan Hilir & - & 3 \\
Rokan Hulu & 11 & 3 \\
Siak & - & 2 \\
Dumai & 3 & 2 \\
Pekanbaru & 1 & 5 \\
& Source: BKPSDM and BKD every district/city (2019) &
\end{tabular}

According to table 1, each district/city opens CPNS formations, both general and special, for people with impairments, with varying numbers according to regional needs. For example, Bengkalis Regency opened 2 special formations for people with disabilities, Indragiri Hilir Regency opened 19 general formations that people with disabilities can apply and 2 special 
formations for people with disabilities, Indragiri Hulu Regency opened 4 special formations for people with disabilities, Kampar Regency opened 1 general formation that people with disabilities can apply and 1 special formation for people with disabilities, Meranti Islands Regency opened 2 special formations for people with disabilities, Kuantan Singingi Regency opened 2 special formations for people with disabilities, Pelalawan Regency opened 2 special formations for people with disabilities, Rokan Hilir Regency opened 3 special formations for people with disabilities, Rokan Hulu Regency opened 11 general formations that people with disabilities can apply and 3 special formations for people with disabilities, Siak Regency opens 2 special formations for people with disabilities, Dumai City opens 3 general formations that people with disabilities can apply and 2 special formations for people with disabilities disability, and Pekanbaru City opened 1 general formation that persons with disabilities can apply and 5 special formations for persons with disabilities.

Based on data from BKPSDM Pekanbaru, the following table shows the number of allocations for CPNS formations for individuals with disabilities and the number of persons with disabilities who have succeeded in becoming civil employees in Pekanbaru City:

Table 2

Allocation of CPNS Formation for Persons with Disabilities and who have become Civil Servants (PNS) in 2019 in Pekanbaru City

\begin{tabular}{ccc}
\hline Position & $\begin{array}{c}\text { Formation } \\
\text { Allocation }\end{array}$ & $\begin{array}{c}\text { Become } \\
\text { Civil Servant }\end{array}$ \\
\hline Class Teacher & 1 & general fill \\
English Teacher & 2 & 2 \\
Public Health Extension & 2 & - \\
Librarian & 1 & general fill \\
Personnel Analyst (General) & 1 & general fill \\
Financial Statement Compiler & 1 & 1 \\
\hline Total & 8 & 3 \\
\hline
\end{tabular}

Source: BKPSDM Pekanbaru

Table 2 shows that the City of Pekanbaru has opened one general formation to which people with disabilities can apply, as well as five special formations for people with disabilities, each with a quota of 8 people, which are currently filled by three people with disabilities who have officially become civil servants, namely two people as English teachers and one person as financial statements. Researchers found a phenomenon, according to data from the Pekanbaru BKPSDM, just a few people with disabilities in Pekanbaru City have registered for the 2019 CPNS acceptance formation. Among people with impairments, there are still those who have low self-esteem and believe they cannot work. Then there's the absence of socializing and information provided through arranging events for disabled individuals, resulting in only a handful of them getting jobs.

This study focuses on equality of employment opportunities (employment rights) for persons with disabilities in Pekanbaru City because employment possibilities for persons with disabilities provide a strong feeling of meaning to the beneficiaries and have a long term impact. Especially if the aid is in the form of appropriate labour to promote the well being of disabled individuals, this study also hopes to learn more about Policy Implementation of Employment Opportunity for Persons with Disabilities in Pekanbaru City Government Agencies and to learn about the factors that determine Policy Implementation of Employment Opportunity for Persons with Disabilities in Pekanbaru City Government Agencies. 
The writers incorporate the results of prior investigations conducted by the authors as comparison material in this study. The following are previous studies related to this research, undertaken by Sri Wahyu Wijayanti entitled "Implementation of Affirmative Policies for Persons with Disabilities in the Employment Sector in DKI Jakarta Province" in 2019 (Wijayanti, 2019). Second, the research was undertaken by Utami Dewi entitled "Policy Implementation of Quota for Persons with Disabilities to Get Jobs in Yogyakarta City" in 2015 (Dewi, 2015). Third, the research was undertaken by Dessy Grestika Ratna entitled "Fulfillment of the Rights of Persons with Disabilities in the Employment Sector in Semarang City (Implementation of Central Java Regional Regulation No. 11 of 2014 concerning the Fulfillment of the Rights of Persons with Disabilities)" in 2018 (Dessy, 2018). Finally, research was undertaken by Karina Putri Dianni entitled "Implementation of the Manpower Placement Training and Debriefing Program for Persons with Disabilities by the West Java Province Manpower Transmigration Service in 2018" in 2019 (Dianni, 2019). The difference between this research and this research is the scope of the locus under study. This study was examined only in Government Agencies, which in previous studies reviewed extensively. In addition, differences are also seen in the place of research and the time of the study.

\section{Methods}

In this study, a qualitative method was used with a descriptive approach. In this study, a qualitative method was used with a descriptive approach. Qualitative research is a research method based on post-positivism philosophy or entrepreneurial philosophy that is used to research in a state of natural objects with the researcher's position as the key instrument. The data collection technique is triangulation (combining observations, interviews, and documentation); the data obtained leads to qualitative data; data analysis is inductive or qualitative; qualitative research results must understand the meaning and unique things, interpret phenomena, and generate hypotheses. (Sugiyono, 2017).

This is a field study, which means the researcher goes straight to the research site to make observations, conduct interviews, and gather the necessary documentation for the study. The research location is the location where the study is carried out. The most crucial phase in qualitative research is establishing the research site because determining the research location means that the object and purpose have been specified to make it easier for the writer to conduct the study. The research location in this study is the Office of BKPSDM Pekanbaru, located in the Pekanbaru City Government Office Complex, Tenayan Raya.

The information for this study came from both oral and written sources and was collected and presented in the form of sentences or narratives. Informants are interviewed or questioned by interviewers who are thought to grasp and master the data, information, or facts needed from a study item (Bungin, 2011). Informants in this study are Head of Procurement and Dismissal BKPSDM Pekanbaru and Persons with disabilities who work in Pekanbaru City Government Agencies (Junior High School 11 Pekanbaru dan Junior High School 18 Pekanbaru). This study uses analytical techniques that explain all data as entirely as possible according to related concepts and theories (Sugiyono, 2017). The data from the interviews were written down as accurately and thoroughly as possible to create field notes. All of the data was then examined qualitatively so that it could be revealed according to reality. 


\section{Results and Discussion}

Policy Implementation of Employment Opportunity for Persons with Disabilities is based on Constitution (UU) No. 8 of 2016 about Persons with Disabilities and Riau Province Regional Regulation No. 18 of 2013 about Persons with Disabilities Protection and Empowerment. Therefore, policy Implementation of Employment Opportunity for Persons with Disabilities is a policy to supply and generate job opportunities for people with disabilities in order to achieve equal employment rights for people with disabilities and people without disabilities.

People with disabilities work for the same reasons that everyone else does: making a living, putting their skills and abilities to use, and contributing to their communities and government organizations. People with disabilities will still be checked for their disability level, selected according to their respective abilities, and accepted if they are able to work in Government Agencies through the acceptance of CPNS. People with disabilities will still be checked for their disability level, selected according to their respective abilities, and accepted if they can work. namely:

The Merilee S. Grindle implementation approach is discussed, along with two indicators,

\section{Content of Policy}

\section{Interest Affected}

The target group's interests are linked to various interests that influence how a policy is implemented (Agustino, 2020). For example, determining policy based on needs or resolving community issues (target groups). As a result, policies must be implemented to appropriately address the community's demands and problems.

The employment opportunity policy for persons with disabilities is implemented based on the interests of persons with disabilities who need work in order to improve their welfare, do not face discrimination, and receive the recognition that persons with disabilities can work despite their limitations, according to the results of interviews with policy implementers and target groups, namely persons with disabilities who work in government agencies. According to one of the people with disabilities who work in Pekanbaru City Government Agencies, this policy is genuinely intended for people with disabilities who have the competence and are allowed to work in government agencies, including himself, who is classified as a person with mild disability and is eligible to participate in CPNS 2019 acceptance.

\section{Type of Benefits}

The type of benefit is to demonstrate that a policy must demonstrate the positive impact it has when it is implemented (Agustino, 2020). For example, if a policy is created to address a community problem, the problem must be addressed with the intended policy to be beneficial.The benefits of the employment opportunity policy for persons with disabilities, according to the results of interviews with policy implementers and target groups, namely persons with disabilities who work in government agencies, are the fulfilment of basic needs for persons with disabilities, ensuring the implementation of social interaction of persons with disabilities in the community, improving the welfare of persons with disabilities, and develop a society that values diversity and distinction, often known as an inclusive society.

A policy that allows people with impairments to work encourages the community to work hard. With enthusiasm possessed by people with disabilities, they will naturally be motivated 
not to be lazy at work because people with disabilities who have limits do not see constraints as hurdles to achievement.

\section{Extent of Change Envision}

A policy has a target to be achieved (Agustino, 2020). The degree of change is a positive change that occurs due to the existence of a policy that is created and implemented. A measure of a policy's success can be seen in the difference between before and after the policy is implemented.

According to the results of interviews with policy implementers and target groups, namely persons with disabilities who work in government agencies, the degree of change desired by policy implementation of employment opportunities for persons with disabilities in government agencies is that there is no discrimination against persons with disabilities, people with disabilities are offered the same career chances as the general public, and they compete after being assessed for their level of disability and approved based on their abilities, transforming the notion that people with disabilities are powerless into a feeling of empowerment.

The feeling of being helpless or powerless can come from anyone, including a disabled person's family. However, a person with a disability will undoubtedly become more empowered for his family due to his work. As a result, even a disabled person can become the family's primary breadwinner and improve their financial status.

\section{Site of Decision Making}

Policy implementers are not without flaws, and as a result, policy implementers occasionally devise alternative ways and make decisions to bring policy to fruition. Decisionmaking is the act of choosing between two or more problem-solving alternatives. According to a policy's objectives, it can be regarded as an evaluative action to achieve the best results.

According to the results of interviews with policy implementers and target groups, namely persons with disabilities who work in government agencies, the site of decision making on difficulties that arise during the execution of the job opportunity policy for people with disabilities is set in stone, specifically, the cancellation (disqualification) of participation if a mistake occurs. On the other side, implementers aim to avoid mistakes as much as possible by confirming twice.

According to BKPSDM's Head of Procurement and Dismissal statement, verification checks were conducted twice, the first by the verifier and the second by the supervisor. Because there are three examinations in total, the chances of an error are pretty low. However, there will be a final check by Badan Kepegawaian Negara (BKN). If the verifier or supervisor makes an error, BKN will identify it. If an error is discovered, the participant will be disqualified.

\section{Program Implementor}

Knowledgeable and capable implementers are required (Agustino, 2020). The policy's implementation program must also be carried out in accordance with the policy's contents, in accordance with the needs, on target, and in the correct environment, and, of course, the program's selection must affect the policies developed so that the policy's level of success is as predicted.

According to the results of interviews with policy implementers and target groups, namely persons with disabilities who work in government agencies, the program on the job opportunity policy for persons with disabilities, meaning the acceptance of Candidates for Civil Servants (CPNS) with the formation of persons with disabilities, has been appropriately and adequately 
implemented, specifically implementing acceptance but also paying attention to the level of disability that can work and with the formation of persons with disabilities, persons with disabilities feel they have the same possibilities and are viewed in their own country as the general population (average). Therefore, this case indicates that BKPSDM, as the program implementer, is competent in its fields and responsibilities, with proof of well-executed program implementation.

\section{Resources Committed}

The engagement of resources is inextricably linked to the effectiveness of a policy. Human resources, time resources, and financial resources are all resources that aid in implementing a successful policy.

a. Human resources

Human resources are the most significant and influential resources. They are implementers who assist in the implementation of policies. The policy's implementers must also be competent and act in accordance with their respective sectors to ensure that no mistakes are made.

According to the results of interviews with policy implementers and target groups, namely persons with disabilities who work in government agencies, the number of human resources involved in the employment opportunity policy for persons with disabilities is sufficient. In the implementation of the acceptance of CPNS with disabilities, the implementing committees, both administrative examiners and doctors, who check the disability level of persons with disabilities are also specialists who master their fields to find out whether they are able to work or not, specifically an occupational specialist who focuses on identifying a person's health risks in the workplace.

According to data from BKPSDM, the implementation of CPNS acceptance involves the Mayor as the person in charge, Deputy Mayor as a deputy in charge, City Regional Secretary as chairman, Assistant General Administration as vice-chairman I, Assistant for Government and People's Welfare as deputy chairman II, Assistant for Economics \& Development as vicechairman III, Head of BKPSDM as secretary, as well as members namely Head of BAPPEDA, Head of BPKAD, Inspectorate Inspector, Head of Dinas Pendidikan, Head of Dinas Kesehatan, BKPSDM employees who have been selected, and occupational specialists.

\section{b. Finansial resources}

Human resources and the availability of financial resources are also critical to the policy's success. Financial resources are money provided by the government for the implementation of programs.

Based on the results of interviews with policy implementers, financial resources in the job opportunity policy for persons with disabilities come from Anggaran Pendapatan Belanja Daerah (APBD) Pekanbaru, there is no separate fund for disabled people because all CPNS acceptance funds, both general and disability, are combined and not separated.

c. Time resource

The use of available time impacts policy implementation; for example, by utilizing this time, it is possible to recruit workers with disabilities.

According to the results of interviews with policy implementers and target groups, namely persons with disabilities who work in government agencies, from the start of the CPNS acceptance program for individuals with disabilities until completion and getting NIP from 
public servants with disabilities who have been accepted, time resources in the employment opportunity policy for persons with disabilities are used throughout the year. Furthermore, for those with disabilities, the registration and processing time is likewise regarded as adequate.

\section{Context of Policy}

\section{Power, Interest, and Strategy of Actor Involved}

A program for implementing a policy can also measure the implementer's power capacity, the target group's interests, and the implementer's strategy for realizing these interests and assist an assessment of the opportunities for fulfilling the policy's objectives.

According to the results of interviews with policy implementers and target groups, namely persons with disabilities who work in government agencies, the power over policy implementation of employment opportunities for persons with disabilities in Pekanbaru City Government Agencies is by BKPSDM Pekanbaru. While the targets of this policy are apparent, specifically the welfare interests of people with disabilities, who have access to the same job prospects as the general public in government institutions.

The strategy to realize this policy is the steps and actions taken by the implementer. In this employment opportunity policy for persons with disabilities in a government agency, the strategy of BKPSDM is to provide information and increase awareness. In the implementation process, the implementers involved are genuinely in accordance with their fields with two checks (verification) to avoid mistakes.

\section{Institution and Regime Characteristic}

A policy and the target group of the policy indicate the characteristics of the institutions and authorities who will implement the policy.

According to the results of interviews with policy implementers and target groups, namely persons with disabilities who work in government agencies, The implementation of employment opportunities policies for people with disabilities in government agencies, particularly the implementation of the CPNS acceptance program for people with disabilities in Pekanbaru City, is carried out by relevant regional offices in accordance with their primary duties and functions, namely BKPSDM Pekanbaru, which is in charge of determining disability formations that will be opened based on needs and various considerations.

\section{Compliance and Responsiveness}

The policy's implementer must become more sensitive to the demands of the target group in order to get their full support and raise their understanding of the policy's implementation process so that it can be implemented appropriately.

According to the results of interviews with policy implementers and target groups, namely persons with disabilities who work in government agencies, the compliance of the implementers or implementers of the employment opportunity policy for persons with disabilities in government agencies is very appropriate so that the main objectives of the policy are realized well too. Meanwhile, the responsiveness of policy implementers is also good, and there is a service for asking questions. Still, there is a lack of socialization, so people with disabilities seek additional information on their own rather than directly from BKPSDM. They are also unaware of the service for asking questions from BKPSDM. 


\section{Influencing Factors of Policy Implementation of Employment Opportunity for Persons with Disabilities in Pekanbaru City Government Agencies}

\section{Purpose of Policy}

A policy must have a goal for the policy to be implemented properly, explicitly, and in the appropriate direction and avoid different problems or misunderstandings between the implementor and the target group that may arise during the process. The policy's success is also determined by the achievement of the policy's objectives. The goals must also be in line with current social, cultural, and economic conditions in order to achieve a high success rate.

According to the results of interviews with policy implementers and target groups, namely persons with disabilities who work in government agencies, implementors and target groups agree on the goal of this government agency's policy on employment opportunities for people with disabilities, which is to improve the welfare of people with disabilities by giving them equal opportunities to work in government agencies based on their skills and abilities. In addition, the goal of this policy is to be used as a reference to see if a policy has been correctly implemented. Of course, this government agency's employment opportunity policy for people with disabilities has been running and realized well.

\section{Human Resources}

Human resources are unquestionably crucial to a policy's success. Human resources are in charge of putting programs into action.

According to the results of interviews with policy implementers and target groups, namely persons with disabilities who work in government agencies, There are a total of 30 program implementers, including 20 verifiers, ten supervisors, and occupational specialists. The number of human resources involved in implementing the policy is sufficient. In collaboration with Dinas Kesehatan, which selects occupational specialist doctors who are competent in this field, can identify health risks that a person may face in the workplace. Therefore, it is clear that with qualified implementers and strong cooperation between implementers and stakeholders, the policy of employment opportunities for persons with disabilities is efficiently implemented in Pekanbaru City government agencies.

\section{Economic Conditions}

External factors also influence the success of a policy, that is, economic conditions. Economic conditions determine the target group to whom the policy will be implemented. By looking at the economic conditions in society, especially people with disabilities, the economic conditions that existed before the policy are considered, and the projected economic conditions can be calculated after the policy is implemented.

According to the results of interviews with policy implementers and target groups, namely persons with disabilities who work in government agencies, the economic conditions of people with disabilities are mostly lower middle class and entrepreneurs as tailors and traders. Therefore, by looking at the economic conditions, the policy on employment opportunities for persons with disabilities in government agencies is determined. With this policy, it is hoped that changes in the economic conditions of persons with disabilities will be better by participating in the CPNS acceptance program and working in Pekanbaru City government agencies. 


\section{Response and Target Group Participation}

The influence of group participation on the implementation of a policy is also essential. A policy will not be implemented adequately if the target group is not passionate and participates.

According to the results of interviews with policy implementers and target groups, namely persons with disabilities who work in government agencies, the response and participation of persons with disabilities has been enthusiastic. Still, only some of them are educated and feel capable. More are terrified of the bizarre perspectives that people with disabilities often receive, resulting in a lack of will and uneducated many.

\section{Conclusion}

Policy Implementation of Employment Opportunity for Persons with Disabilities in Pekanbaru City Government Agencies concluded that it went well. However, there are still deficiencies, and there is a need for improvement in the aspect of implementing responsiveness. For example, it can be seen that during field research, researchers discovered that information about the availability of a specific formation for people with impairments had to be sought out by the community without any notification from the implementer, namely Badan Kepegawaian dan Pengembangan Sumber Daya Manusia (BKPSDM) and for the service of asking questions, there are still a lot of people who don't know and are stumped when it comes to overcoming the obstacle up against.

Many persons with disabilities are unaware that the acceptance of Candidates for Civil Servants (CPNS) also opens special formations for them due to a lack of socialization and information from BKPSDM Pekanbaru regarding the availability of special formations for people with disabilities. In fact, this special formation for people with disabilities can encourage people with disabilities to remain confident despite their limits because they will compete against other people with disabilities based on their respective talents. Only a few persons with impairments registered due to a lack of socializing and information. In this case, BKPSDM Pekanbaru should do more public outreach to inform the public about the availability of special formations for people with disabilities at CPNS admissions and service facilities for asking questions about potential difficulties.

\section{References}

Agustino, L. (2016). Dasar-Dasar Kebijakan Publik (Edisi Revisi). In Alfa Beta.

Agustino, L. (2020). Dasar-Dasar Kebijakan Publik: Edisi Revisi Ke-2. Bandung, Alfabeta.

Bungin, B. (2011). Penelitian Kualitatif, edisi kedua. Jakarta: Prenada Media Group.

Dessy, G. R. (2018). Pemenuhan Hak Penyandang Disabilitas Bidang Ketenagakerjaan Di Kota Semarang (Implementasi Perda Jawa Tengah No. 11 Tahun 2014 Tentang Pemenuhan Hak Penyandang Disabilitas). Diponegoro University.

Dewi, U. (2015). Implementasi Kebijakan Kuota bagi Penyandang Disabilitas untuk Mendapatkan Pekerjaan di Kota Yogyakarta. Natapraja, 3(2).

Dianni, K. P. (2019). Implementasi Program Pelatihan dan Pembekalan Penempatan Tenaga 
Kerja bagi Penyandang Disabilitas oleh Dinas Tenaga Kerja Transmigrasi Provinsi Jawa Barat pada tahun 2018.

Habibi, M., \& Nugroho, R. (2019). Pelatihan Desain Grafis Untuk Memperoleh Kesempatan Kerja Di Upt Pelatihan Kerja Surab. JPUS: Jurnal Pendidikan Untuk Semua, 3(1), 17-26.

Ladipa, C., Aristi, N., \& Alnashava, P. (2020). Motif Penggunaan Media Sosial Bagi

Penyandang Disabilitas Netra (Studi Kasus Mengenai Motif Penggunaan Facebook Bagi Penyandang Disabilitas Netra Pada Terapis Pijat). Mediakom: Jurnal Ilmu Komunikasi, 3(2), 197-209.

Manan, B. (2001). Perkembangan Pemikiran dan Pengaturan Hak Asasi Manusia di Indonesia. Yayasan Hak Asasi Manusia, Demokrasi, dan Supremasi Hukum.

Priyono, D., \& Wirathi, I. (2016). Analisis Hubungan Ekspor, Pertumbuhan Ekonomi, dan Kesempatan Kerja di Provinsi Bali: Pengujian Vector Auto Regression. E-Jurnal Ekonomi Pembangunan Universitas Udayana, 5(12), 165288.

Sugiyono. (2017). Metode Penelitian Kualitatif: Untuk Penelitian yang Bersifat: Eksploratif, Enterpretitif, dan Konstruktif. In Alfabeta.

Wahab, A. (2016). Keberpihakan Kebijakan Pemerintah Pada Sektor Usaha Rakyat Perspektif Ekonomi Islam (Studi Kasus Keberlangsungan Pasar Tradisional). Tsaqafah, 12(1), 167186.

Wahab, S. A. (2008). Pengantar Analisis Kebijakan Publik. Universitas Muhammadiyah Malang Press. Malang.

Wijayanti. (2019). Analisis Implementasi Kebijakan Afirmatif Bagi Penyandang Disabilitas dalam Bidang Ketenagakerjaan di Provinsi DKI Jakarta.

Winarno, B. (2008). Globalisasi: peluang atau ancaman bagi Indonesia. Erlangga. 